\title{
Diagnostic ultrasound performed by a physician as a dialog
}

\author{
Ärztliche Ultraschalldiagnostik im Dialog
}

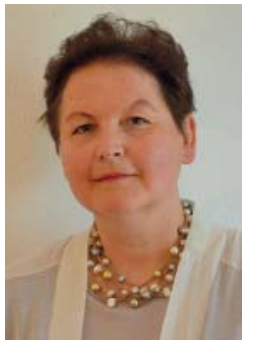

Deike Strobel

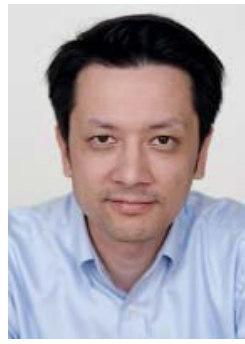

Stefan Meng
Correspondence

Dr. Deike Strobel

University of Erlangen, Internal medicine I, Ulmenweg 18,

91058 Erlangen, Germany

Tel.: ++49/9131/8535000

Fax: ++49/9131/853525

deike.strobel@uk-erlangen.de

Bibliography

DOI https://doi.org/10.1055/a-0593-8473

Published online: 2018

Ultraschall in Med 2018; 39: 251-252

(c) Georg Thieme Verlag KG, Stuttgart · New York

ISSN 0172-4614
Diagnostic ultrasound is an integral part of clinical patient care. All clinical disciplines take advantage of this simple, quick, and side effect-free technique to the benefit of patients. Patients appreciate having ultrasound performed by a physician. Why? Increasing digitalization is resulting in a decrease in the amount of attention patients receive from physicians [1]. Patients value a competent, symptom-oriented examination that can be immediately adapted to a change in focus. Physicians listen during an ultrasound examination, ask targeted questions, consider differential diagnoses, rule out inaccurate diagnoses, give the patient their undivided attention, and evaluate ultrasound findings in view of the patient (face-to-face). The patient is immediately informed not only of findings but also of individual consequences. This includes ruling out acute diseases and communicating harmless incidental findings and requires a high level of competence and empathy when communicating newly detected serious tumor diagnoses. The ultrasound spectrum is broad as evidenced by the scientific and clinical articles in the current EJU issue. The DEGUM recommendations on hygiene in ultrasound and endoscopic ultrasound specify the level of medical expertise required for the practical use of diagnostic and interventional ultrasound [2]. All clinical disciplines represented by the DEGUM sections and working groups contributed to these important recommendations.

A high level of competence is required with respect to not only the technical implementation of ultrasound but also the interpretation of findings [3]. There is a reason why medical education and specialist training typically take longer than 10 years. How will ultrasound develop if digitalization (remote diagnoses) or the delegation of ultrasound examinations to non-physician personnel separate physicians and patients? In radiology imaging (X-ray, CT, MRI), this is standard procedure in most cases. Could this model also work for ultrasound? Ultrasound is not just the visualization of body structures in real time and the standardized recording of measurements. Experienced physicians change the focus, implementation, and scope of an examination in real time, including changing the US technique, e. g. supplementary contrast-enhanced ultrasound. All of this greatly affects the interpretation of findings. Therefore, clinical evaluation of the situation and a corresponding change of the examination focus are performed simultaneously with image interpretation in a dialog with the patient. The abovementioned medical knowledge and clinical experience impact the examination particularly in this regard. For this reason there must be a direct connection between the examiner's brain and hand. Only is this way can good and reliable diagnoses with a shorter time to diagnosis and justifiable costs be achieved with ultrasound.

The delegation of parts of diagnostic ultrasound to non-physician personnel is currently being discussed. This discussion is being primarily held by radiologists. The delegation of diagnostic ultrasound to specially trained ultrasound assistants in radiology departments is standard practice in non-European countries like the USA, Australia, Canada, and Great Britain. In a very interesting editorial, Mostbeck G. \& Kathrein H. commented on the ultra-short module-based training of independent "sonographers" initiated in 2017 by the Austrian Society of Radiologic Technologists, a program from which the Austrian Society of Ultrasound in Medicine and Biology has expressly distanced itself [6]. In Germany ultrasound is an integral part of the requirements for specialist training for various medical disciplines and is considered a valuable diagnostic tool for clinicians [4]. The German Society of Ultrasound in Medicine and Biology recently emphasized the importance of ultrasound performed by a specialist in clinical disciplines [5]. Optimal benefit for the patient combined with positive effects regarding time, cost, and radiation exposure can only be achieved with the synergy between diagnostic ultrasound performed by a physician and clinical expertise ("clinical ultrasound"). For the sake of patients, ultrasound will hopefully continue to be performed by physicians for a long time! 


\section{Ärztliche Ultraschalldiagnostik im Dialog}

Die Ultraschalldiagnostik ist integraler Bestandteil der klinischen Patientenversorgung. Alle klinischen Disziplinen nutzen die Möglichkeiten dieser faszinierenden Technik, die einfach, schnell und nebenwirkungsfrei verfügbar ist - zum Wohle der Patienten. Patienten schätzen den fachärztlichen Ultraschalluntersucher. Warum? Ärztliche Zuwendung wird in Zeiten politisch gewünschter Digitalisierung dem Patienten zunehmend seltener zuteil [1]. Patienten schätzen die kompetente symptomorientierte Untersuchung. Ärzte hören während der Ultraschalluntersuchung zu, fragen gezielt nach und durchdenken gleichzeitig Differentialdiagnosen, schließen aus und fokussieren. Ärzte bewerten Ultraschallbefunde im Angesicht des Patienten (face-to-face). Befunde werden nicht nur unmittelbar mitgeteilt, sondern ärztlich mit den individuellen Konsequenzen für den Patienten kommuniziert. Dies umfasst den Ausschluss akuter Erkrankungen, Entwarnung bei harmlosen Zufallsbefunden und erfordert hohe Kompetenz und Empathie bei der Übermittlung neu festgestellter schwerwiegender Tumordiagnosen. Das Spektrum im Ultraschall ist breit, wie sich auch in den wissenschaftlichen und klinischen Beiträgen der aktuellen EJU zeigt. Die DEGUM-Empfehlungen zur Hygiene in der Sonografie und Endosonografie belegen die ärztliche Expertise in der praktischen Anwendung des diagnostischen und interventionellen Ultraschalls [2]. Alle klinischen Fachdisziplinen, vertreten durch die Sektionen und Arbeitskreise der DEGUM, haben an diesen wichtigen Empfehlungen gemeinsam gearbeitet.

Eine hohe Qualifikation ist nicht nur in der technischen Ausführung des Ultraschalls, sondern auch in der Einschätzung von Befunden erforderlich [3]. Nicht umsonst dauert die Ausbildung des Arztes im Medizinstudium und in der Facharztausbildung in der Regel länger als 10 Jahre. Wohin entwickelt sich der Ultraschall, wenn Digitalisierung (Ferndiagnosen) oder die Delegation der Ultraschalluntersuchung an nichtärztliches Personal Arzt und Patient trennen? In der Beurteilung der radiologischen Schnittbildverfahren (Röntgen, CT, MRT) ist dies bis auf wenige Ausnahmen der Normalfall. Könnte das auch im Ultraschall funktionieren? Ultraschall ist nicht nur die Bilddarstellung der Körperstrukturen "real-time” oder die standardisierte Erfassung von Messwerten. Der klinisch erfahrene Arzt verändert in Echtzeit Fragestellung, Durchführung und Umfang der Untersuchung einschließlich Wechsel der US-Technik selbst, z. B. ergänzende Kontrastmittelsonografie. All das nimmt wesentlich Einfluss auf die Interpretation. So erfolgt synchron zur Interpretation der Bilder im Dialog mit dem Patienten eine klinische Bewertung der Situation und eine entsprechende Veränderung des Ductus der Untersuchung. Genau hier wirken das oben genannte ärztliche Wissen und die klinische Erfahrung auf die Untersuchung ein.
Genau deshalb müssen das Untersucherhirn und die Untersucherhand direkt miteinander verbunden sein. Nur so entstehen mit Ultraschall gute und verlässliche Diagnosen, die den diagnostischen Weg verkürzen und die eingesetzten Kosten rechtfertigen.

Aktuell wird die Delegation von Teilbereichen der Ultraschalldiagnostik an nichtärztliches Personal diskutiert. Diese Diskussion erfolgt vorwiegend durch Radiologen. In nichteuropäischen Ländern wie den USA, Australien, Kanada und in Großbritannien ist die Delegation der Ultraschalldiagnostik an speziell geschulte Sonografie-Assistenten in Radiologie-Abteilungen der Normalfall. Jetzt kommentieren Mostbeck G und Kathrein H die 2017 vom Berufsverband der RadiologietechnologInnen initiierte Kurz-Modulausbildung „Sonografeurs in Österreich“, von der sich die ÖGUM ausdrücklich distanziert hat - ein lesenswertes Editorial [6]. In Deutschland ist der ärztliche Ultraschall fester Bestandteil der Weiterbildungsordnung verschiedenster Fachdisziplinen und wird als wertvolles Diagnostikum des klinisch tätigen Arztes verstanden [4]. Die Bedeutung des fachärztlichen Ultraschalls in den klinischen Fächern wurde aktuell von der DEGUM besonders hervorgehoben [5].

Die Synergie der ärztlichen Ultraschalldiagnostik mit der klinischen Fachexpertise kommt dem Patienten zugute. Der ärztliche Ultraschall bleibt den Patienten hoffentlich lange erhalten!

In Deutschland ist der ärztliche Ultraschall fester Bestandteil der Weiterbildungsordnung verschiedenster Fachdisziplinen und wird als wertvolles Diagnostikum des klinisch tätigen Arztes verstanden [4, 7]. Die Bedeutung des fachärztlichen Ultraschalls in den klinischen Fächern wurde aktuell von der DEGUM besonders hervorgehoben [5].

References

[1] Maio G. Medicine and the holistic understanding of the human being: ultrasound examination as dialog. Ultraschall in Med 2014; 35: 98-107

[2] Müller T, Martiny H, Merz E et al. DEGUM-Empfehlungen zur Hygiene in Sonografie und Endosonografie. Ultraschall in Med 2018; 39: 1-21

[3] Seitz K. Quality assurance for ultrasound diagnostics in Germany - a never-ending story. Ultraschall in Med 2012; 33: 517-519

[4] Seitz K. Who's Doing Your Scan? The German Perspective on Ultrasound Services: Ultrasound is More Than a Technique, it's a Medical Art. Ultraschall in Med 2017; 38: 661-663

[5] Heling K. Statement from the DEGUM board regarding the editorial entitled "Who's Doing Your Scan? A European Perspective on Ultrasound Services". Ultraschall in Med 2018; 39: 11-13

[6] Mostbeck G, Kathrein H. Ultrasound in transition - sonographers and student sonographers in austria. Ultraschall in Med 2018; 39: 1-6

[7] Arning C. High-level Carotid Ultrasound Must be Performed by a Physician. Ultraschall in Med 2017; 38: 664. doi:10.1055/s-0043-122446 